\title{
A simple spectrophotometric method of assay of forward motility of goat spermatozoa
}

\author{
G. C. Majumder and C. K. Chakrabarti* \\ Indian Institute of Chemical Biology, Calcutta 700 032, India
}

\begin{abstract}
Summary. Spermatozoa from the cauda epididymidis were suspended in modified Ringer solution containing $2 \%$ Ficoll and $50 \mu \mathrm{l}$ were placed at the bottom of a standard optical cuvette containing $1.3 \mathrm{ml}$ modified Ringer. This amount was just sufficient to cover the entire width of the light beam. Vigorously motile spermatozoa that moved upwards into the light beam were registered continuously as an increase of absorbance at $545 \mathrm{~nm}$ with a spectrophotometer equipped with a recorder. The first slope of the curve represents an index of the velocity of the population of cells showing the fastest motility. When measured in this system forward motility activity (expressed as units) increased linearly with cell concentration. Ficoll at concentrations of $1-5 \%$ had no effect on the values recorded but $250 \mu \mathrm{M}$-p-chloromercuribenzoic acid completely inhibited motility. The spectrophotometric values did not necessarily correlate with light microscope assessments of forward motility, because the former method provides an assessment of numbers of motile cells and their rate of progression.
\end{abstract}

\section{Introduction}

Forward progression of spermatozoa is an important characteristic for evaluating the quality of semen. The conventional method of visual assessment of flagellar motility by microscopy is highly subjective (Atherton, 1977; Amelar, Dubin \& Schoenfeld, 1980). Methods that have been developed for objective assessment of sperm motility include photography of moving spermatozoa (Liu \& Warme, 1977; Makler, 1978; Acott \& Hoskins, 1978; Katz \& Overstreet, 1981), light scattering using the laser (Shimizu \& Matsumoto, 1977; Frost \& Cummins, 1981) and spectrophotometric monitoring of the return of spermatozoa to random orientation after alignment by flow (Atherton, 1975; Atherton, Radnay \& Polakoski, 1978). However, these methods are so complex that it may be difficult to adopt them for clinical or research studies on sperm motility. Sokoloski, Blasco, Storey \& Wolf (1977) described a spectrophotometric method for determining the proportion of spermatozoa in human semen showing the most vigorous forward motility. The method consists of layering a semen sample at the bottom of a specially constructed self-masked optical cuvette equipped with an injection port. Spermatozoa that swim upwards against gravity to enter the light path of the spectrophotometer are registered with a recorder as an increase of absorbance at $545 \mathrm{~nm}$. This results in a time-dependent increase of absorbance. The forward motility index of the most vigorous motile population of spermatozoa has been calculated on the basis of the initial linear rate of increase of absorbance, i.e. the first slope of the curve (Sokoloski et al., 1977; Levin, Shofer \& Greenberg, 1980). This slope is again dependent on the sperm numbers in the cuvette (Levin et al., 1980). The present study describes an improvement of the spectrophotometric method of motility assay developed by Sokoloski et al. (1977).

* Present address: Glaxo Laboratories (India) Ltd, Pilgrim Road, Cuttack-3, Orissa, India. 


\section{Materials and Methods}

Reagents. Ficoll-400 was obtained from Pharmacia (Sweden). Penicillin and p-chloromercuribenzoic acid (PCMB) were products of Sigma Chemical Co. (St Louis, MO, U.S.A.). Epididymides of adult goats were obtained fresh from the local slaughter houses. Spermatozoa were extracted from the cauda epididymidis within 2-4 hours after slaughter.

Preparation of spermatozoa. Spermatozoa were obtained from the cauda epididymidis by the procedure of Majumder \& Biswas (1979) with some modifications (Chaudhuri \& Majumder, 1983). Cells were extracted at room temperature $\left(32 \pm 1^{\circ} \mathrm{C}\right)$ in a modified Ringer's solution (RPS medium: $119 \mathrm{~mm}-\mathrm{NaCl}, 5 \mathrm{~mm}-\mathrm{KCl}, 1 \mathrm{~mm}-\mathrm{CaCl}_{2}, 1.2 \mathrm{~mm}-\mathrm{MgSO}_{4}, 10 \mathrm{~mm}$-glucose, $16.3 \mathrm{~mm}-$

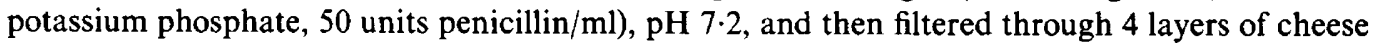
cloth. The sperm preparations $\left(2-4 \times 10^{8}\right.$ cells $\left./ \mathrm{ml}\right)$ were left at room temperature until $(5-20 \mathrm{~min})$ analysed for motility.

Numbers of spermatozoa in the samples were determined with a haemocytometer. Spermatozoa that showed forward progression were noted under a light microscope at $\times 150$ magnification (Chaudhuri \& Majumder, 1983). An aliquant of the freshly extracted sperm preparation $\left(0.50-0.65 \times 10^{6}\right.$ cells $)$ containing epididymal plasma $(\sim 0.3 \mathrm{mg}$ protein) was incubated in a total volume of $0.5 \mathrm{ml}$ RPS medium for $10 \mathrm{~min}$ at room temperature before assessing sperm motility in a haemocytometer. For the microscopic method of assay of forward motility (expressed as $\%$ ) all cells which showed some degree of progressive motility were counted.

Spectrophotometric assay of sperm forward motility. Modifications of the turbidimetric method of Sokoloski et al. (1977) were used. The preparation of freshly extracted cauda epididymal spermatozoa $(100 \mu \mathrm{l})$ was mixed with $100 \mu 110 \%$ Ficoll in a total volume of $0.5 \mathrm{ml}$ RPS medium. Immediately after mixing $(\sim 1 \mathrm{~min})$ the cell suspension $(50 \mu \mathrm{l})$ was carefully layered with a Hamilton syringe at the bottom of a standard cuvette (capacity $4.0 \mathrm{ml} ; 1 \mathrm{~cm}$ light path) containing $1.3 \mathrm{ml}$ RPS medium. The depth of the bottom area of the cuvette (masked in the spectrophotometer by the cuvette holder) through which light will not pass through was about $1.0 \mathrm{~mm}$, including the cell layer which was about $0.5 \mathrm{~mm}$ deep. Sperm forward motility was measured spectrophotometrically as an increase of absorbance at $545 \mathrm{~nm}$ as the cells moved to the light path after crossing the $1.0 \mathrm{~mm}$ mask by swimming upwards against gravity. Continuous change in absorbance as a function of time was monitored with a Gilford spectrophotometer- 250 equipped with a recorder (model 6051). The amount of the buffer in the cuvette $(1.3 \mathrm{ml})$ was just sufficient to cover the entire width of the light beam $(\sim 12 \mathrm{~mm})$. The volume of the medium in the light path was about $1.25 \mathrm{ml}$. This method therefore permits assay of all the cells that are in the light path at any particular time, i.e. those cells that crossed the bottom-mask. After reaching maximal absorbance $\left(\mathrm{A}_{\mathrm{Eq}}\right)$ the contents of the cuvettes were mixed and the absorbance for all the cells was noted $\left(A_{T}\right)$. The percentage of cells that showed vigorous forward motility to move upwards into the light path was therefore calculated as: $\left(\mathrm{A}_{\mathrm{Eq}} / \mathrm{A}_{\mathrm{T}}\right) \times 100$.

A unit of forward motility activity of the most vigorous group of spermatozoa (responsible for the first slope) has been defined as an initial linear increase of absorbance of $0.01 / \mathrm{min}$ under the standard assay conditions. Specific activity of sperm forward motility was expressed as units of forward progression per $10^{7}$ spermatozoa. The results of the motility assays shown as spectrophotometric scans are representative of at least 3 experiments.

\section{Results}

\section{Basic method}

The presence of Ficoll in a concentration as low as $1 \%$ in the assay medium (see below) produced enough viscosity of the medium to permit smooth layering of spermatozoa at the bottom of the cuvette without causing any appreciable disturbance of the buffer and sperm interface. This 
was confirmed with non-motile (cold-shocked) as well as motile spermatozoa. There was little increase of absorbance, at least during the short period of the spectrophotometric assay, when dead or non-motile cells were layered at the bottom of the cuvettes. Absorbance at $545 \mathrm{~nm}$ increased linearly with increase of cell concentration up to $4.0 \times 10^{6} \mathrm{cells} / \mathrm{ml}$ and, under the linear conditions of assay, an absorbance value of 1.0 corresponded to a sperm concentration of $6.9 \pm 0.9 \times 10^{6}$ cells/ml (mean \pm s.d. from 16 experiments).

\section{Time course}

As shown in Text-fig. 1, after the addition of cells in the cuvette turbidity increased linearly during the early phase of the motility assay and then the rate of increase of absorbance decreased until maximal absorbance was obtained. The tiny mask at the bottom of the cuvette caused a short lag phase before the initial linear increase of absorbance. The initial slope of the curve was used as an index of the velocity of the fastest group of spermatozoa. Freshly extracted sperm preparations had about $17 \%$ (average of 13 experiments: range $8-28 \%$ ) of spermatozoa with vigorous forward motility. The observed increase of absorbance was not due to Brownian movement of assay constituents because there was no detectable increase of absorbance in the absence of spermatozoa during the period $(\sim 10 \mathrm{~min})$ of the assay.

The pattern shown in Text-fig. 1 was a frequently observed, relatively simple tracing of the sperm forward motility. As reported by Sokoloski et al. (1977) complex patterns of the tracing were also observed that involved two or more slopes as a result of greater heterogeneity of the velocity of spermatozoa. About $30 \%$ of the samples that were analysed showed complex patterns of the tracing. The numbers of cells that moved to the light beam at any instant can be calculated as absorbance $\times$ cell numbers per $\mathrm{ml}$ at unit absorbance $\times$ volume of buffer in the light path in $\mathrm{ml}$, i.e. absorbance $\times\left(6.9 \times 10^{6}\right) \times 1.25$ or absorbance $\times 8.7 \times 10^{6}$. A unit of forward motility therefore represents a linear entry of $8.7 \times 10^{4}$ spermatozoa/min into the light path since the unit has been defined as an increase of 0.01 absorbance/min.

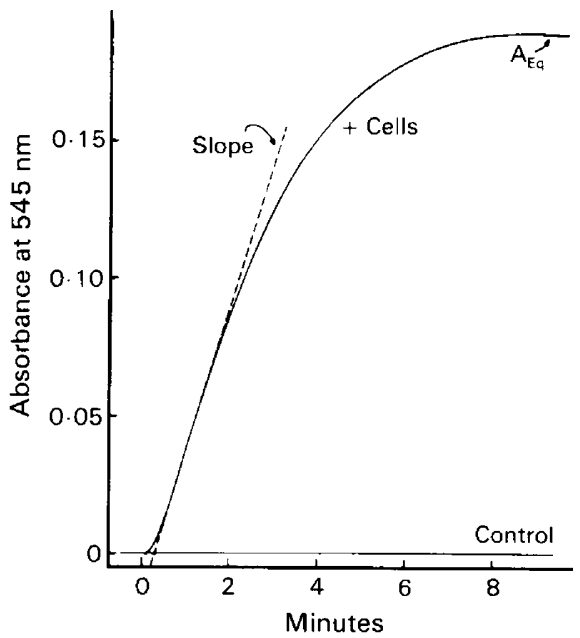

Text-fig. 1. A representative spectrophotometric tracing showing the time course of the assay of sperm forward motility. The assays were carried out under standard assay conditions without (control) or with $6.8 \times 10^{6}$ goat spermatozoa from the cauda epididymidis. The slope of the initial curve can be calculated from the broken line. $A_{E q}=$ absorbance at equilibrium. 


\section{Concentration of spermatozoa}

The effects of various concentrations of spermatozoa on the measurement of sperm motility are shown in Text-fig. 2. Forward motility activities as measured by the initial slope of the curve were $1 \cdot 0,2 \cdot 2$ and $4 \cdot 0$ units when the cells layered in the cuvettes were $1 \cdot 5,3 \cdot 0$ and $6.0 \times 10^{6}$, respectively. Thus the amount of forward motility increased linearly with sperm concentration. The specific forward motility activity of freshly extracted spermatozoa was about 13.4 units (average of 14 experiments: range 5.4-24.0)/107 cells. The data in Text-fig. 2 also demonstrate that values of $A_{\mathrm{Eq}}$ also increase nearly linearly with cell concentration. It is thus apparent that the percentage of highly motile spermatozoa remained nearly unchanged $(\sim 12 \%)$ even when the assays were carried out with various cell concentrations.

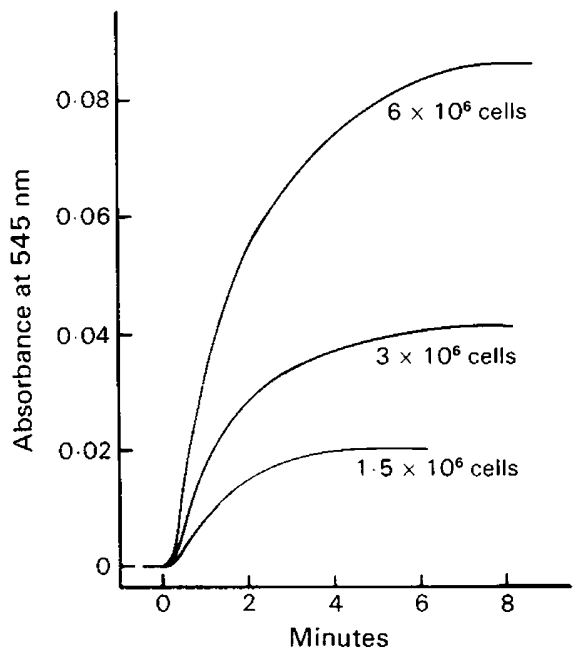

Text-fig. 2. A representative spectrophotometric tracing showing the effect of various concentrations of spermatozoa on the assay of sperm forward motility.

\section{Volume of cell suspension}

Keeping the same sperm numbers but varying the volumes of cell suspension layered at the bottom of the cuvette $(25-75 \mu \mathrm{l})$ had no appreciable effect on the forward motility activity of spermatozoa. For example, the forward motility activities as measured by the initial slopes of the spectrophotometric tracings (not shown) of a representative experiment were $2 \cdot 4,2.8$ and 2.8 units when the volumes of layered cell suspensions were 25,50 and $75 \mu 1$ respectively $\left(4 \times 10^{6}\right.$ cells in each case). These results demonstrated further that the proportion of the highly motile sperm population remained nearly unchanged $(24-29 \%)$ when the assays were carried out with various volumes of the cell suspension.

\section{Concentration of Ficoll}

At a relatively low concentration Ficoll is highly viscous but it has very low osmotic pressure due to its high molecular weight. Based on these characteristics Ficoll has been widely used for the isolation of various cell types along a gradient (Acott \& Hoskins, 1978; Pretlow \& Pretlow, 1977). The presence of Ficoll at $1 \%$ concentration in the sperm suspension greatly facilitated the layering of the cells at the bottom of the cuvettes. Spermatozoa showed forward motility values of $47 \pm 2,46$ 
\pm 3 and $44 \pm 1 \%$ (mean \pm s.e.m. of 4 determinations) in the presence of $0,2.5$ and $5 \%$ Ficoll when assayed by the microscopic method, indicating that Ficoll (up to $5 \%$ ) had no significant effect $(P>$ $0 \cdot 3$ ) on sperm motility. When the effect of Ficoll on sperm motility was determined spectrophotometrically, the forward motility activities were $11 \cdot 1 \pm 2 \cdot 3,9 \cdot 7 \pm 0.6$ and $10 \cdot 1 \pm 1.7$ units/10 (mean \pm s.e.m. of 4 experiments) when the Ficoll concentrations in the assays were 1, 3 and $5 \%$ respectively $(P>0.5)$. The proportions of the sperm suspensions that showed vigorous forward progression were $13.2 \pm 3 \cdot 2,14.3 \pm 2.4$ and $13.7 \pm 2.2$ (mean \pm s.e.m., $n=4$ ) when the concentrations of Ficoll in the assays were 1,3 and $5 \%$ respectively $(P>0 \cdot 7)$. These results confirm that Ficoll $(1-5 \%)$ has no appreciable effect on sperm motility at least during the short period (up to 10 $\mathrm{min}$ ) required for the motility assays.

\section{Spectrophotometric and microscopic methods}

Values of forward motility of a limited number of sperm preparations as assayed by the spectrophotometric and microscopic methods have been compared in Table 1. Some correlations were apparent (e.g. samples 1, 6, 11 and 13) but other values were discrepant (e.g. sample 7 compared with sample 1). The differences between these two methods of motility assessment appear to be due to the fact that the microscopic method takes into consideration only the numbers of cells with forward progression but not their velocity whereas the spectrophotometric method is based on not only the motile cell numbers but also their velocity. It is therefore clear that the spectrophotometric method gives a more accurate estimate of the forward motility index than does the subjective microscopic method. Lack of correlation between these two methods of motility assays was also observed by Sokoloski et al. (1977).

Table 1. Comparison of the values of sperm forward progression as measured by the microscopic and the spectrophotometric methods

\begin{tabular}{ccc}
\hline $\begin{array}{c}\text { Sample } \\
\text { no. }\end{array}$ & $\begin{array}{c}\text { Microscopic } \\
\text { assessment } \\
(\%)\end{array}$ & $\begin{array}{c}\text { Spectrophotometric } \\
\text { measurement } \\
\text { (units/107 cells) }\end{array}$ \\
\hline 1 & 25 & $2 \cdot 8$ \\
2 & 30 & $3 \cdot 6$ \\
3 & 30 & $5 \cdot 8$ \\
4 & 32 & $7 \cdot 0$ \\
5 & 35 & $2 \cdot 8$ \\
6 & 35 & $6 \cdot 5$ \\
7 & 40 & $2 \cdot 9$ \\
8 & 40 & $6 \cdot 9$ \\
9 & 40 & $7 \cdot 0$ \\
10 & 40 & $8 \cdot 9$ \\
11 & 42 & $8 \cdot 6$ \\
12 & 43 & $7 \cdot 0$ \\
13 & 50 & $10 \cdot 8$ \\
\hline
\end{tabular}

\section{Effect of PCMB}

PCMB, a thiol reagent that has high affinity for-SH groups, is a well known potent inhibitor of sperm motility. PCMB at a concentration of $0.25 \mathrm{~mm}$ completely inhibited goat sperm motility measured by both methods (Text-fig. 3). At a lower concentration ( $50 \mu \mathrm{M})$, PCMB had little effect on the forward motility measured microscopically but caused significant inhibition of motility measured spectrophotometrically, presumably due to inhibition of the velocity of forward 


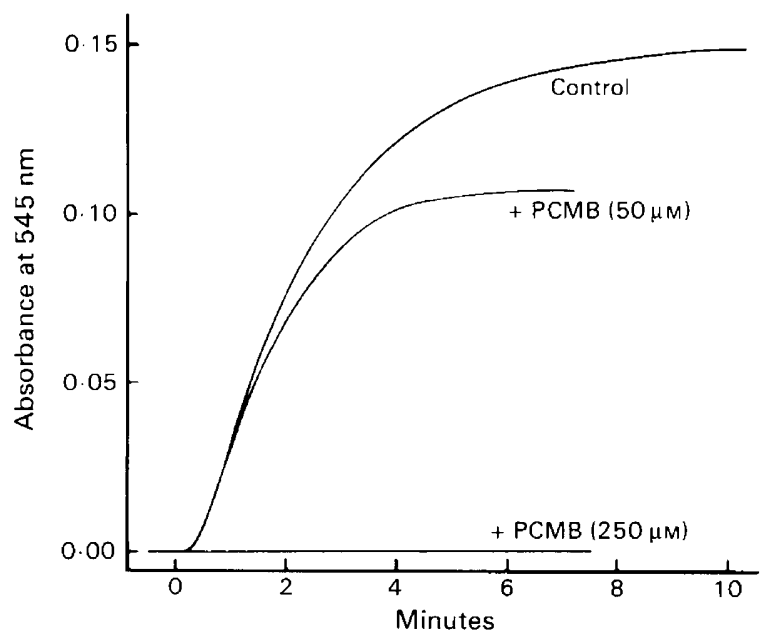

Text-fig. 3. A representative spectrophotometric tracing showing the effect of $p$-chloromercuribenzoic acid (PCMB) on the assay of sperm $\left(5 \times 10^{6}\right.$ cells) forward motility under the standard assay conditions.

progression. These results therefore provide further support to the validity of the spectrophotometric method described for the assessment of sperm motility.

\section{Discussion}

The present study describes a simplified spectrophotometric method for the objective estimation of sperm forward motility. Based on the initial slope of the tracing, sperm forward motility activity can be expressed as units that represent the linear entry of defined numbers of spermatozoa $/ \mathrm{min}$ into the light path. The turbidimetric method described earlier (Sokoloski et al., 1977) required specially constructed cuvettes with an injection port for smooth layering of spermatozoa. The method described here does not require any special cuvettes since the incorporation of Ficoll (1$2 \%$ ) in the sperm suspension permitted smooth layering of cells using readily available standard cuvettes. At such low concentrations the Ficoll had no effect on the sperm motility.

The amount of buffer (above the cell layer) used by Sokoloski et al. (1977) was much greater than that required to cover the entire width of the light beam $(10 \mathrm{~mm})$, and so spermatozoa that crossed the upper mask were no longer detected in the recorder. However, as the assay progressed, it is possible that some of the spermatozoa that penetrated the upper mask re-entered the light beam in response to gravity or sedimentation because of failure of motility (Nevo \& Mohan, 1969) and these changes could have complicated the interpretation of the motility patterns. Using these assay conditions, Sokoloski et al. (1977) estimated the percentage of spermatozoa with vigorous forward motility on the basis of the assumption that, at equilibrium, cell concentration will be uniform throughout the entire cuvette. However, this assumption seems to be incorrect since we have found that the cell concentration above the light beam is markedly lower than that in the light beam (data not shown). The present method, however, largely eliminates these technical problems since the amount of buffer used above the cell layer is just adequate to cover the entire width of the light beam, thereby allowing assaying at any moment all the cells that have moved into the light path. Due to a small masked volume $(\sim 0.1 \mathrm{ml})$ at the bottom of the cuvette more than $90 \%$ of the forwardly motile cells will be registered in the recorder at equilibrium when the rate of entry of the cells to the light path from the bottom is likely to be the same as that of the exit of cells from the light beam to the bottom. 
We thank Professor B. K. Bachhawat for his interest in this work; the Council of Scientific and Industrial Research, New Delhi, for a research fellowship (C.K.C.); and Miss Kamala Chakraborty and Mrs Snigdha Banerjee for technical assistance.

\section{References}

Acott, T.S. \& Hoskins, D.D. (1978) Bovine sperm forward motility protein partial purification and characterization. J. biol. Chem. 253, 6744-6750.

Amelar, R.D., Dubin, L. \& Schoenfeld, C. (1980) Sperm motility. Fert. Steril. 34, 197-215.

Atherton, R.W. (1975) An objective method of evaluating Angus and Hereford sperm motility. Int. J. Fertil. 20, 109-112.

Atherton, R.W. (1977) Evaluation of sperm motility. In Techniques of Human Andrology, vol. 1. Ed. E. S. E. Hafez. Elsevier/North Holland, Amsterdam.

Atherton, R.W., Radnay, E.W. \& Polakoski, K.L. (1978) Spectrophotometric quantitation of mammalian spermatozoan motility. I. Human. Biol. Reprod. 18, 624-628.

Chaudhuri, D.P. \& Majumder, G.C. (1983) Evidence for the reconstitution of motility by epididymal plasmaprotein factor(s) in immotile washed spermatozoa from goat cauda epididymis. Andrologia 15 (in press).

Frost, J. \& Cummins, H.Z. (1981) Motility assay of human sperm by photon correlation spectroscopy. Science, N.Y. 212, 1520-1522.

Katz, D.F. \& Overstreet, J.W. (1981) Sperm motility assessment by video micrography. Fert. Steril. 35, 188-193.

Levin, R.M., Shofer, J. \& Greenberg, S.H. (1980) A quantitative method for determining the effect of drugs on spermatozoal motility. Fert. Steril. 33, 631635 .
Liu, Y.T. \& Warme, P.K. (1977) Computerized evaluation of sperm cell motility. Computers, Biomed. Res. 10, 127-138.

Majumder, G.C. \& Biswas, R. (1979) Evidence for the occurrence of an ecto-(adenosine triphosphatase) in rat epididymal spermatozoa. Biochem. J. 183, 737743.

Makler, A. (1978) A new multiexposure photography method for objective human spermatozoal motility determination. Fert. Steril. 30, 192-199.

Nevo, A.C. \& Mohan, R. (1969) Migration of motile spermatozoa into sperm-free medium and the 'dilution' effect. J. Reprod. Fert. 18, 379-381.

Pretlow, T.G. \& Pretlow, T.P. (1977) Separation of viable cells by velocity sedimentation in an isokinetic gradient of Ficoll in tissue culture medium. In Methods of Cell Separation, Vol. I, pp. 171-191. Ed. N. Catsimpoolas. Plenum Press, New York.

Shimizu, H. \& Matsumoto, G. (1977) Light scattering study on motile spermatozoa. IEEE Trans Biomed. Eng. 24, 153-156.

Sokoloski, J.E., Blasco, L., Storey, B.T. \& Wolf, D.P. (1977) Turbidimetric analysis of human sperm motility. Fert. Steril. 28, 1337-1341.

Received 31 May 1983 